\title{
EFFECT OF SOCIAL STRATIFICATION ON EXTENSION-FARMER CONTACT AMONG POULTRY FARMERS IN DELTA STATE, NIGERIA
}

\author{
Ofuoku, Albert Ukaro
}

Dept. of Agricultural Economics and Extension, Delta State University,Asaba Campus, PMB 95074, Asaba, Delta State, Nigeria

Accepted: $06^{\text {th }}$ May 2015

\begin{abstract}
This study was carried out in Delta State, Nigeria to determine the effect of social stratification on extension - farmer contact among poultry farmers. Multi-stage random sampling technique was used to select 108 poultry farmers for the study. The data were collected with the use of questionnaire and structured interview schedule. Data collected were analyzed with the use of descriptive statistics and inferential statistics were used to test the hypotheses. The result of the study showed that the variables of wealth, occupation, family ancestry, religion, level of education, gender and farm size were used to determine class structure. There were differences in frequency of contact between extension agents and farmers based on farm size and level of education. Hypothesis 1 (there is no significant difference in the frequency of extension-farmer contact between small, medium and large scale poultry farmers) showed significant difference in frequency of contact among group of poultry farmers $(F=8.583)$. Hypothesis 2 (there is no significant difference in frequency of extension contact with poultry farmers based on farm size and level of education as class determinants) indicated that the level of education, farm size, marital status and income influence contact between farmers and extension agents. It was recommended that extension agents should endeavour to give equal treatment to every class of poultry farmers, more extension agents should be employed by Delta State Agricultural Development Programme (DTADP) and the DTADP should set up inspectorate/supervisory committee that will make sure that every class of farmers is adequately visited.
\end{abstract}

Keywords: Poultry farmers, Social stratification, class, extension-farmer contact, norminalist theory, heterophily.

\section{INTRODUCTION}

Stratification refers to the process of assigning individuals to a patterned structure of unequal groups with such group tending to persist across generations (Ekong, 2003). It is the hierarchical arrangement of a social classes, castes and strata within a society. Social Stratification is regarded quite differently by principal perspectives of sociology (Emuoboria, 2009). According to Saunders (1990), in modern western society, stratification depends on social and economic classes comprising three main layers: upper class, middle class and lower class. Each class is further sub divided into smaller classes, related to occupation.

The factors that determine class vary widely from one society to another. Even within a society various people may have very distinct conceptions about the factors that make one higher or lower in the social hierarchy. Kerbo (1996) is of the view that some questions frequently asked when trying to define class include the most important criteria in distinguishing classes; the number of class division that exist; and extent to which individuals recognize these division if they are meaningful. In most societies, classes exist whether silently or glaringly. In most parts of Nigeria, especially in the Niger Delta region, one class is determined by personal or household wealth, occupation, educational level and family background.

Income inequality is one of the most important

\footnotetext{
*Corresponding author: ofuoku@yahoo.com
} 
determinants of social class. Consistent data shows that those in higher classes have higher income than those in lower classes. Inequality also persists where controlling for occupation, the condition at work vary greatly depending on class. Those in the upper middle class and the middle class enjoy more diversity of job opportunities and are able to exhibit some authority. Kerbo (1996) states that while middle class workers may suffer alternating conditions or lack of job satisfaction, blue-collar workers are the one who have to worry about health hazards, injury and even death.

One other important consequence of social class is inequality in access to services. Chukwu (1997) discovered that there was significant difference in frequency of contact between extension agent and the large scale poultry farmers and frequency of contact between extension agent and small holder farmer in Imo State, Nigeria. This invariably means that in the agricultural system, the consequences of social class are also experienced or observed.

The situation is that the rich framers are more respected than the small holder farmers. Similarly, when the extension agent shares similar certain attributes with the farmers, such as beliefs, educational level and social status, they tend to interact more frequently. In most cases news enters a system through higher status and more innovative members (Agbamu, 2006). That is to say according to Agbamu (2006) that high degrees of homophily mean that the elite individuals interact mainly with each other and the innovation does not trickle down to the non -elite.

The implication of this phenomenon is that homophily is a blockage of information flow to the lower class of farmers in a rural social system, this is more so when those in the middle and upper classes does not often interact with those in the lower class.

It is a known fact, as studies have shown that the bulk of foods produced in Nigeria and Delta State in particular are produced by small scale farmers. There seem to be low frequency of contact between extension agents and small scale farmers than large scale farmers. This is further buttressed by Osuagwu et al. (2005) who discovered in their study that $81.25 \%$ of fisher folks had no access to extension service. It was also established that the contact that existed with small scale poultry farmers was poor as large scale poultry farmers had frequent contact with extension agents (Ofuoku and Ajieh 2005). There seem to be a pointer towards inequality in our social system. An investigation into the effect of inequality of the Delta Central Agricultural Zone of Delta State is worth carrying out.

Various studies have been concentrated on access to extension farmer contact and none has been conducted to ascertain the major differentials in access to extension service and information among farmers. This study will be of benefit to extension managers in policy review and formulation. It will also serve as a guide to extension administrators and supervision of field extension agents, especially in this era when there is the dearth of field extension personnel.

\section{MATERIALS AND METHODS}

The study area is Delta state. It has roughly between longitude $5^{\circ} 00$ and $6^{\circ} 45$ east and latitude $5^{\circ} 00$ and $6^{\circ} 30$ north. The total area of the state is 7,440 square kilometres one third of this is swampy and water logged.

Delta State is bounded on the north side by Edo State, on the east by Anambra state, on the south by Baylesa state and the west by Atlantic Ocean. Delta state consists of 25 local government areas. The state is divided into three agricultural zones by Delta State Agricultural Development Programme (DTADP) these zones are Delta North, Central and South Agricultural zones with Agbor, Effurun and Warri as the Zonal headquarters respectively.

Many (1800) poultry farms registered with DTADP exist in the state as the climatic condition and the culture of the people of the state 
favour rearing of chickens. There are many large, medium and small scale poultry farmers in the state with the small scale framers having highest population. The DTADP (2008) classified the poultry farmers according to farm sizes based on the population of bird reared. The classifications are as follows:

$$
\begin{aligned}
& \text { Small scale }=1000-4999 \text { birds } \\
& \text { Medium scale }=5000-7999 \text { birds } \\
& \text { Large scale }=8000 \text { and above birds. }
\end{aligned}
$$

Multi stage random sampling technique was used for the selection of the respondent from the list of registered farmers in the zones headquarters of DTADP. For the study, ten (10) local government areas were randomly selected out of the twenty five (25) local government areas on the basis of four (4) local government areas to be selected from each agricultural zone. From each of the four (4) local government areas selected from each agricultural zones, $5 \%$ of the registered farmers with DTADP in each class with populations ranging between $60-63$ farmers were randomly selected to result to three (3) small scale, three (3) medium scale, three (3) large scale poultry farmers as classified by DTADP. This gave us a total of 36 small scale, 36 medium scale and 36 large scale poultry farmers. The selection was done from a list of poultry farmers accessed from the zones office of Delta State Agricultural development programme. In all a sample size of 108 respectively was used for this study.

Data for the study were collected with the use of structured interview scheduled to be administered to the farmers that have no formal education and less literate farmers. Questionnaires were used to collect information from formally educated farmers.

Data collected were analyzed as follows

Objective i was analyzed with the use of descriptive statistics such as frequency counts and percentages
Objective ii was treated using mean derived from 4 point type likert scales of strongly agree $=4$, agree $=3$, disagree $=2$, strongly disagree $=1$ with a cut off mean of 2.50 .

Objective iii was addressed with the use of frequency count and percentage, and the hypothesis.

Hypothesis $1\left(\mathrm{Ho}_{1}\right)$ was treated by using a two way analysis of variance

\section{RESULTS AND DISCUSSION Socio- economic characteristics of respon- dents}

Table 1 shows that most $(64.8 \%)$ of the respondents were men. This indicates that men are more involved in poultry farming than women. This confirms the findings of Ofuoku (2010) as he made a similar observation in his study.

Most $(83.3 \%)$ of them were in the age range of 31-50 years. The implication is there most of them are in their youthful years and are agile enough to meet up with the challenges of managing poultry farm.

As far as educational level is concerned, most $(52.7 \%)$ of the poultry farmers had tertiary education ranging from Nigerian Certificate in Education (NCE) to $\mathrm{PhD}$ degree. The high percentage of the population attributed to the introduction of pert-time and distance learning programme. Very few $(2.8 \%)$ of them had no formal education, while $34.3 \%$ had secondary education and $10.2 \%$ had primary education. Those without formal education and those who had primary education are found mostly among the small scale farmers, while those who acquired secondary and tertiary education are mostly among the medium and large scale farmers. Education is believed to be one of the salient variables that enhance adoption of new agricultural technologies (Ofuoku et al, 2008). This is because; educated farmers tend to behave as progressives since they are not risk averse and easily 
Table 1: Socio-Economic Characteristics of Respondents

\begin{tabular}{|c|c|c|c|c|}
\hline Variables & $\begin{array}{l}\text { Small Scale } \\
\text { Farmers } n=36 \\
\end{array}$ & $\begin{array}{l}\text { Medium scale } \\
\text { Farmers } n=36 \\
\end{array}$ & $\begin{array}{c}\text { Medium scale } \\
\text { Farmers n }=36 \\
\end{array}$ & $\begin{array}{l}\text { Total } \\
\text { Farmers }=108\end{array}$ \\
\hline \multicolumn{5}{|l|}{ Gender } \\
\hline Male & $21(58.2)$ & $26(72.2)$ & $23(63.9)$ & $70(64.8)$ \\
\hline Female & $15(41.3)$ & $10(27.8)$ & $13(36.3)$ & $38(35.2)$ \\
\hline \multicolumn{5}{|l|}{ Age (years) } \\
\hline $20-30$ & $6(16.7)$ & $2(5.6)$ & $1(2.8)$ & $9(8.3)$ \\
\hline $31-40$ & $17(47.2)$ & $13(36.1)$ & $5(13.9)$ & $35(32.4)$ \\
\hline $41-50$ & $9(47.2)$ & $7(19.40$ & $12(33.3)$ & $28(25.0)$ \\
\hline $51-60$ & $3(8.3)$ & $9(25.0)$ & $15(41.7)$ & $27(25.0)$ \\
\hline Above 60 & $1(2.8)$ & $4(11.1)$ & $3(8.3)$ & $8(7.4)$ \\
\hline \multicolumn{5}{|l|}{ Level of Education } \\
\hline No formal education & $3(8.3)$ & $0(0)$ & $0(0)$ & $3(2.8)$ \\
\hline Primary education & $11(30.6)$ & $0(0)$ & $0(0)$ & $11(10.6)$ \\
\hline Secondary education & $18(50.0)$ & $13(31.6)$ & $6(16.7)$ & $37(34.3)$ \\
\hline NCE/OND & $4(11.1)$ & $9(25.0)$ & $10(27.8)$ & $23(21.3)$ \\
\hline B.Sc/HND & $0(0)$ & $5(13.9)$ & $10(27.8)$ & $15(13.9)$ \\
\hline M.Sc & $0(0)$ & $7(19.4)$ & $8(22.2)$ & $15(13.9)$ \\
\hline Ph.D & $0(0)$ & $2(5.6)$ & $2(5.6)$ & $4(3.7)$ \\
\hline \multicolumn{5}{|l|}{ Marital Status } \\
\hline Married & $29(80.6)$ & $34(94.4)$ & $31(86.1)$ & $94(87.0)$ \\
\hline Single & $3(8.3)$ & $0(0)$ & $0(0)$ & $3(2.8)$ \\
\hline Widow & $1(2.8)$ & $2(5.6)$ & $4(11.1)$ & $7(6.5)$ \\
\hline Divorced & $3(8.3)$ & $0(0)$ & $1(2.8)$ & $4(3.7)$ \\
\hline Separated & $0(0)$ & $0(0)$ & $0(0)$ & $0(0)$ \\
\hline \multicolumn{5}{|c|}{ Farming Experience (years) } \\
\hline $1-5$ & $5(13.9)$ & $3(8.3)$ & $1(2.8)$ & $9(8.3)$ \\
\hline $6-10$ & $7(19.4)$ & $2(5.6)$ & $5(13.9)$ & $14(13.0)$ \\
\hline $11-15$ & $19(52.8)$ & $11(30.6)$ & $9(25.0)$ & $39(36.1)$ \\
\hline $16-20$ & $2(5.6)$ & $14(38.9)$ & $7(25.0)$ & $23(21.3)$ \\
\hline $21-25$ & $1(2.8)$ & $5(13.9)$ & $9(25.0)$ & $15(13.9)$ \\
\hline Above 25 & $2(5.6)$ & $1(2.8)$ & $5(13.9)$ & $8(7.4)$ \\
\hline \multicolumn{5}{|c|}{ Farm size (number of birds) } \\
\hline 2000 and below & $17(47.2)$ & $0(0)$ & $0(0)$ & $17(15.7)$ \\
\hline $2001-4000$ & $13(36.1)$ & $0(0)$ & $0(0)$ & $13(12.0)$ \\
\hline $4001-5000$ & $6(16.7)$ & $15(41.7)$ & $0(0)$ & $21(19.4)$ \\
\hline $5001-6000$ & $0(0)$ & $9(25.0)$ & $0(0)$ & $9(8.3)$ \\
\hline $6001-7000$ & $0(0)$ & $7(19.4)$ & $0(0)$ & $7(6.5)$ \\
\hline $7001-8000$ & $0(0)$ & $5(13.9)$ & $24(66.7)$ & $29(26.9)$ \\
\hline Above 8000 & $0(0)$ & $0(0)$ & $12(33.3)$ & $12(11.1)$ \\
\hline \multicolumn{5}{|c|}{ Farm income (monthly) } \\
\hline $4000-20,000$ & $19(52.8)$ & $0(0)$ & $0(0)$ & $19(17.6)$ \\
\hline $21,000-40,000$ & $13(36.1)$ & $0(0)$ & $0(0)$ & $13(12.0)$ \\
\hline $41,000-60,000$ & $14(11.1)$ & $12(33.3)$ & $0(0)$ & $16(14.8)$ \\
\hline $61,000-80,000$ & $0(0)$ & $15(41.7)$ & $0(0)$ & $15(13.9)$ \\
\hline $81,000-100,000$ & $0(0)$ & $6(16.7)$ & $3(8.3)$ & $9(8.3)$ \\
\hline $101,000-120,000$ & $0(0)$ & $3(8.3)$ & $10(27.8)$ & $13(12.0)$ \\
\hline Above 120,000 & $0(0)$ & $0(0)$ & $23(63.9)$ & $23(21.3)$ \\
\hline
\end{tabular}


understand innovations and adopt Education also helps them to find information about technologies which they adopt.

Most $(87.0 \%)$ were married and therefore have responsibilities and commitments to their respective families. This tends to make them take their farming activities seriously. Meanwhile, most (36.1\%) of them had 11-15 years of poultry farming experience. This implies that most of them are qualified to give useful information emanating from their various experiences, for this study.

Most $(47.2 \%)$ of the small- scale poultry farmers had farm sizes of 2,000 birds and below. Most $(66.7 \%)$ of the medium scale farmers had farm sizes of between 5,000 and6, 000 birds, while most $(66.7 \%)$ of the large scale farmers had sizes 8,000 birds. According to DTADP (2008), small scale farms have 1000-4999 birds, medium scale, 5000-7999 birds and large scale, 8000and above birds.

Most (52.8\%) of the small-scale farmers realise between N4, 000 (\$26.67) and N20, 000 (\$ 133.33) monthly as farm income. Most $(41.7 \%)$ of the medium scale farmers make between $\mathrm{N}$ 61,000 (\$ 406.67)- N 80,000 (\$533.33) monthly farm income, while most (63.9\%) of them make above N 120,000 (\$800) monthly as farms income. These im- plies poultry farming, in spite of the risks involved is lucrative.

\section{Determinants of class structure as indicated by the respondents in the study area}

The determinants of social class (Table 2) in the study area, especially in the rural communities included wealth (means $=3.65$ ), occupation (mean 3.37), family ancestry $($ mean $=2.58)$ religion $($ mean $=2.87)$, level of education $\quad($ mean=3.76), farm size (mean=3.81). Gender (mean=1.72) was not importantly considered as they stratify their various communities. This is congruent with Ekong (2003) he cited of the above significant variables as the points determinants of class in Nigeria and other societies of the world.

\section{Comparative analysis of extension farmer contact (farm size)}

Most (61.1\%) of small scale farmers had no contact with extension agents. Table 3 few $(19.4 \%)$ of medium scale farmers and $8.3 \%$ of large scale farmers had no contact with extension agents monthly. Small scale farmers $(25.0 \%)$, mediums scale farmers $(30.6 \%)$ and large scale farmers $(25.0 \%)$ had one (1) contact with extension agent monthly. Few $(8.3 \%)$ of small scale, $(36.1 \%)$ of medium scale and (44.4\%) of large scale had contact

\section{Table 2: Determinants of Class Structure}

\begin{tabular}{lcccccc}
\hline \multicolumn{1}{c}{ Variables } & $\begin{array}{c}\text { Strongly } \\
\text { Agreed }\end{array}$ & Agreed & Disagreed & $\begin{array}{c}\text { Strongly } \\
\text { Disagreed }\end{array}$ & Score & Mean \\
& & & & & \\
& $(\mathbf{4})$ & $\mathbf{( 3 )}$ & $\mathbf{( 2 )}$ & $\mathbf{( 1 )}$ & & \\
\hline Wealth & $80(320)$ & $21(63)$ & $5(10)$ & $2(2)$ & 394 & 3.65 \\
Occupation & $58(232)$ & $33(99)$ & $7(34)$ & $0(0)$ & 365 & 3.37 \\
Family & $22(88)$ & $30(90)$ & $45(90)$ & $11(11)$ & 279 & 2.58 \\
Ancestry & & & & & & \\
Religion & $44(176)$ & $10(30)$ & $51(102$ & $3(3)$ & 311 & 2.87 \\
Level of & $93(372)$ & $7(21)$ & $5(10)$ & $3(3)$ & 406 & 3.16 \\
Education & & & & & & \\
Gender & $10(40)$ & $20(60)$ & $8(16)$ & $70(70)$ & 186 & 1.72 \\
Farm Size & $88(352)$ & $20(60)$ & $0(0)$ & $0(0)$ & 412 & 3.81 \\
\hline
\end{tabular}


with extension agents two (2) times monthly. Very few small scales $(2.8 \%)$ had three (3) contacts with extension agents monthly while $11.1 \%$ and $13.9 \%$ of medium scale farmers respectively had 3 contacts with extension agents monthly. Also, $2.8 \%$ of small scale farmers, $5.6 \%$ of medium scale farmers and $5.6 \%$ of large scale farmers had 4 contacts with extension agent monthly. On the whole, most large scale farmers had the highest frequency of contact with extension agent, while the medium scale farmers had more frequency of contact with extension agent than the small scale farmers. This is attributed to the fact that extension agents pay more attention to large scale and mediums scale farmers than small scale farmers because of their farm size as they tend to be wealthier than the small scale farmers. Again, educationally they (extension agent) tend to have almost similar educational background with the medium and large scale farmers. This implies that they are homophilous, that is some degree of homophily exist between the medium and large scale poultry farmers and the extension agents. Homophily, according to Agbamu (2006), is the degree to wish pairs of individual who interact are similar in certain attribute, such as belief, education, social status and in others ways.

Individual who are homophilous interact closer to each other than those who are heterophilous. In most cases, new ideas enter a system through higher status and more innovative members, that a high degree of homophily means the elite individuals interact mainly with each others and innovation does not trickle down to non elite(Agbamu, 2006).

The scale of operations of farmers is indicative of the level of income and wealth of the farmers, ceteris paribus. Therefore similar trend will be discovered with level of income and wealth on extension- farmer contact. Extension agents are paying more attention to farmers with high income levels and wealth farmers. This confirmed the findings of Ofuoku and Ajieh (2005) who discovered that extension agent had more contact with commercial poultry farmers than small scale farmers.

Comparatives analysis of frequency of extension-farmer contact with respect to educational level

Table 3: Comparative Analysis of Extension-Farmer Contact

\begin{tabular}{lccc}
\hline $\begin{array}{l}\text { Frequency of Contact } \\
\text { Monthly }\end{array}$ & $\begin{array}{l}\text { Frequency /\% Small } \\
\text { Scale Farmers }\end{array}$ & $\begin{array}{l}\text { Frequency/\% } \\
\text { Medium Scale }\end{array}$ & $\begin{array}{l}\text { Frequency/\% Large } \\
\text { Scale }\end{array}$ \\
\hline 0 time & $22(61.1)$ & $7(19.4)$ & $3(8.3)$ \\
1 time & $9(25.0)$ & $11(30.6)$ & $9(25.0)$ \\
2 times & $3(8.3)$ & $13(36.1)$ & $16(44.4)$ \\
3 times & $1(2.8)$ & $4(11.1)$ & $5(13.9)$ \\
4 times & $1(2.8)$ & $2(5.6)$ & $2(5.6)$ \\
\hline
\end{tabular}

Table 4: Comparative Analysis of Frequency of Extension-Farmer Contact with Respect to Educational Level $(n=108)$

\begin{tabular}{lccccc}
\hline Level of Education & \multicolumn{5}{c}{ Frequency of Extension-Farmer Contact Monthly } \\
\cline { 2 - 6 } & 0 time & 1 time & 2 times & 3 times & 4 times \\
\hline No Formal Education & $2(1.9)$ & $1(0.9)$ & $0(0)$ & $0(0)$ & $0(0)$ \\
Primary Education & $9(8.3)$ & $1(0.9)$ & $1(0.9)$ & $0(0)$ & $0(0)$ \\
Secondary Education & $21(19.4)$ & $5(4.6)$ & $8(7.4)$ & $3(2.8)$ & $1(0.9)$ \\
B.Sc/HND & $0(0)$ & $19(17.6)$ & $3(2.8)$ & $1(0.9)$ & $1(0.9)$ \\
M.Sc & $0(0)$ & $0(0)$ & $18(16.7)$ & $1(0.9)$ & $1(0.9)$ \\
Ph.D & $0(0)$ & $0(0)$ & $2(1.9)$ & $3(2.8)$ & $2(1.9)$ \\
\hline
\end{tabular}

Figures in parentheses are percentages (\%) 
with extension agents two (2) times monthly. Very few small scales $(2.8 \%)$ had three (3) contacts with extension agents monthly while $11.1 \%$ and $13.9 \%$ of medium scale farmers respectively had 3 contacts with extension agents monthly. Also, $2.8 \%$ of small scale farmers, $5.6 \%$ of medium scale farmers and $5.6 \%$ of large scale farmers had 4 contacts with extension agent monthly. On the whole, most large scale farmers had the highest frequency of contact with extension agent, while the medium scale farmers had more frequency of contact with extension agent than the small scale farmers. This is attributed to the fact that extension agents pay more attention to large scale and mediums scale farmers than small scale farmers because of their farm size as they tend to be wealthier than the small scale farmers. Again, educationally they (extension agent) tend to have almost similar educational background with the medium and large scale farmers. This implies that they are homophilous, that is some degree of homophily exist between the medium and large scale poultry farmers and the extension agents. Homophily, according to Ag- bamu (2006), is the degree to wish pairs of individual who interact are similar in certain attribute, such as belief, education, social status and in others ways.

Individual who are homophilous interact closer to each other than those who are heterophilous. In most cases, new ideas enter a system through higher status and more innovative members, that a high degree of homophily means the elite individuals interact mainly with each others and innovation does not trickle down to non elite(Agbamu, 2006).

The scale of operations of farmers is indicative of the level of income and wealth of the farmers, ceteris paribus. Therefore similar trend will be discovered with level of income and wealth on extension- farmer contact. Extension agents are paying more attention to farmers with high income levels and wealth farmers. This confirmed the findings of Ofuoku and Ajieh (2005) who discovered that extension agent had more contact with commercial poultry farmers than small scale farmers.

Comparatives analysis of frequency of extension-farmer contact with respect to educational level

Table 3: Comparative Analysis of Extension-Farmer Contact

\begin{tabular}{lccc}
\hline $\begin{array}{l}\text { Frequency of Contact } \\
\text { Monthly }\end{array}$ & $\begin{array}{l}\text { Frequency } / \% \text { Small } \\
\text { Scale Farmers }\end{array}$ & $\begin{array}{l}\text { Frequency/\% } \\
\text { Medium Scale }\end{array}$ & $\begin{array}{l}\text { Frequency/\% Large } \\
\text { Scale }\end{array}$ \\
\hline 0 time & $22(61.1)$ & $7(19.4)$ & $3(8.3)$ \\
1 time & $9(25.0)$ & $11(30.6)$ & $9(25.0)$ \\
2 times & $3(8.3)$ & $13(36.1)$ & $16(44.4)$ \\
3 times & $1(2.8)$ & $4(11.1)$ & $5(13.9)$ \\
4 times & $1(2.8)$ & $2(5.6)$ & $2(5.6)$ \\
\hline
\end{tabular}

Table 4: Comparative Analysis of Frequency of Extension-Farmer Contact with Respect to Educational Level $(n=108)$

\begin{tabular}{lccccc}
\hline Level of Education & \multicolumn{5}{c}{ Frequency of Extension-Farmer Contact Monthly } \\
\cline { 2 - 6 } & 0 time & 1 time & 2 times & 3 times & 4 times \\
\hline No Formal Education & $2(1.9)$ & $1(0.9)$ & $0(0)$ & $0(0)$ & $0(0)$ \\
Primary Education & $9(8.3)$ & $1(0.9)$ & $1(0.9)$ & $0(0)$ & $0(0)$ \\
Secondary Education & $21(19.4)$ & $5(4.6)$ & $8(7.4)$ & $3(2.8)$ & $1(0.9)$ \\
B.Sc/HND & $0(0)$ & $19(17.6)$ & $3(2.8)$ & $1(0.9)$ & $1(0.9)$ \\
M.Sc & $0(0)$ & $0(0)$ & $18(16.7)$ & $1(0.9)$ & $1(0.9)$ \\
Ph.D & $0(0)$ & $0(0)$ & $2(1.9)$ & $3(2.8)$ & $2(1.9)$ \\
\hline
\end{tabular}

Figures in parentheses are percentages $(\%)$ 
Table 4 reveals the formally educated farmers had more contact with extension agents than those who had no formal education. Further, revelation shows that those who acquired tertiary education $(17.6 \%)$ had at least 1 contact with extension agent monthly. Most (21.4\%) of the farmers who had various tertiary education qualification had the normal 2 contacts with extension agents monthly, while those who had primary and secondary education $(8.3 \%)$ had 2 contacts with extension agent monthly. In all, those who had tertiary education had most frequent contact with extension agents than the rest of the farmers. This is attributed to the fact that some degree of homophily exist between the farmers who had tertiary education and extension agents. Homophily is the degree to which pairs of individuals who interact are similar in certain attribute such as beliefs, education, social status etc. This promotes communications between this group of poultry farmers and extension agents. This finding is congruent with Chukwu (1997) who discovered that highly educated farmers had more contact with extension agents than those who had little or no education in Imo State Nigeria. According to Dennis Wrong's norminalist theory, people identify themselves with a particular class based on personal characteristics and they interact mainly with people in this class of simlar personal characteristics (Kerbo, 1996).

\section{Hypothesis $\mathbf{1}\left(\mathrm{H}_{01}\right)$ testing.}

There are no significant differences in frequency of extension farmer contact based on farm size and educational level.

Result (Table 5) of the ANOVA shows that there are significant difference in frequency of extension -farmer contact based on farm size $(\mathrm{f}=8.043)$ and level of framers education ( $\mathrm{f}=17.401)$ this could be attributed to the fact that extension agent pay more attention to th farmers with medium and large farm sizes and highly educated farmers. As a result of the high value medium and large scale farmers and highly educated farmers place on extension services and the fact that the extension agent and the set of farmers share similar attributes (degree of homophily). In a typical Nigerian and Delta society in particular medium and large scale farmer are held in high esteemed because they belong to higher class than the less non-formally educated ones. As a result of this, people pay more attention to issues concerning them.

This has prompted the difference in frequency of extension- farmer contact considering the two attribute of farm size and level of education. This could also be attributed to the influence of medium and large scale farmers, hence wealth farmer and educated citizen - in rural communities of Delta State and Nigeria at large. The influence they wield is as a result

Table 5: ANOVA showing the difference in Frequency of Extension Contact based on Farm Size and Education Level

\begin{tabular}{|c|c|c|c|c|c|c|}
\hline Variables & Source & $\begin{array}{l}\text { Sum of } \\
\text { Squares } \\
\end{array}$ & $\begin{array}{l}\text { Degree of } \\
\text { Freedom } \\
\end{array}$ & $\begin{array}{l}\text { Mean } \\
\text { Squares } \\
\end{array}$ & $\mathbf{F}$ & Sig. \\
\hline \multirow[t]{2}{*}{ Farm size } & $\begin{array}{l}\text { Between } \\
\text { Group }\end{array}$ & 176.400 & 2 & 88.200 & 8.04 & $0.06 \mathrm{~s}$ \\
\hline & $\begin{array}{l}\text { Within } \\
\text { Group } \\
\text { Total }\end{array}$ & $\begin{array}{r}131.600 \\
308.000\end{array}$ & 12 & $\begin{array}{l}10.967 \\
99.161\end{array}$ & & \\
\hline \multirow{3}{*}{$\begin{array}{l}\text { Educational } \\
\text { Level }\end{array}$} & Between & 746.800 & 5 & 149.360 & 17.401 & $0.000 \mathrm{~s}$ \\
\hline & $\begin{array}{l}\text { Within } \\
\text { Group }\end{array}$ & 206.000 & 24 & 8.583 & & \\
\hline & Total & 952.800 & 2 & & & \\
\hline
\end{tabular}

Degree of Freedom: 2/12; 5/24 Level of significance $=0.05 ; \mathrm{s}=$ significant 
of the group they belong to in the process of assigning individuals to a patterned structure of unequal groups tending to persist across generations.

This confirms Dennis Wrong's nominalist theory. The norminalists define class based on the characteristics that people share in a given class such as education, wealth, income, occupation and family background. People with one or more common characteristics such as a formation identify and frequently identify with each other. Kerbo (1996) suggest that, according to the norminalist theory people identify frequently with each other based on the common characteristic which they share.

Table 6: Tobit Analysis of Influence of Selected Indicators of Social Class on Extension-Farmer Contact

\begin{tabular}{lcc}
\hline Variables & Coefficient & $\mathbf{P} / \mathbf{Z} />\mathbf{z}$ \\
\hline Education $\left(\mathrm{X}_{1}\right)$ & 0.294 & $0.0034^{*}$ \\
Farm size $\left(\mathrm{X}_{2}\right)$ & -0.682 & $0.0291^{*}$ \\
Gender $\left(\mathrm{X}_{3}\right)$ & -0.272 & 0.8996 \\
Marital status & 1.110 & $0.0000^{*}$ \\
$\left(\mathrm{X}_{4}\right)$ & & \\
Income $\left(\mathrm{X}_{5}\right)$ & 0.520 & $0.0950^{*}$ \\
\hline
\end{tabular}

\section{CONCLUSION}

There is unequal frequency of contact between extension agent and poultry farmers in Delta state based on farm size and level of education. Social stratification has effect in the frequency of contact between extension agent and farmers in Delta state. This is so as most of the extension agents frequently visited with the farmers with whom they share similar characteristic.

\section{REFERENCE}

Agbamu JU 2006 Essentials of agricultural communication in Nigeria; Victoria Island, lagos; Malthouse press. I S B N, 0073530425 / 9780073530420.145Pp.

Chukwu AO 1997 An assessment of ADP on agricultural development of Imo State of Nigeria. Unpublished M.sc thesis. Rivers StateUniversity of Science and Technology, Port Harcout, Nigeria.

DTADP 2008 Agricultural extension manual: Poultry farming in Delta State.

Asaba, Delta State, Nigeria: Delta State Agricultural Development Programme.

Ekong EE 2003 An introduction to rural sociology. Uyo Nigeria: Dove educational publishers .

Emuoboria A 2009 Effect of social classification on social interaction in Nigerian Societies. Unpublished BSc Project .Department of Agricultural Economics and Extension, Delta State University,Abraka,Nigeria.

Kerbo HR 1996 social stratification and inequality: class conflict in historical and comparative perspective. New York: McGraw-Hill.

Ofuoku AU 2010 Communication process and effectiveness of agricultural technology messages in poultry production in Delta State, Nigeria. Unpublished $\mathrm{PhD}$ Thesis. Rivers State University of science and thecnology. Port Harcourt.

Ofuoku AU, Egho EO and Emijeke EC 2008 Integrated pest management (IPM) adoption among farmers in central Agro-ecological Zone of Delta State, Nigeria. African Journal of Agricultural Research. 3(12):1852-856.

Ofuoku AU and Ajieh PC 2005 Sources of information on animal health management among poultry farmers in Delta State, Nigeria. Proceedings of the $10^{\text {th }}$ Annual conference; Animal science association of Nigeria. Held 
Sept 12-15, at the University of AdoEkiti.

Osuagwu CN, Ofuoku AU and Ebewore SO 2005 Rural migrant fisher folks access to extension service in Oshimili North Local Government Area of Delta State. Proceedings $19^{\text {th }}$ Annual Conference of Farm Management Association of Nigeria held October 18-20, 2005 at Delta State University, Asaba Campus, Asaba.

Saunders P 1990 Social class and stratification. Abirgdon, Oxon, UK: Rout/ edge, Taylor and Francis group. 